pain, swelling and exudate were gone. The larynx was again free from cancer (Fig. 9). April 1, the laryngeal interior remained healthy; the patient was in robust health. No report of return has been received so far, July 30 .

\section{NOTE ON THE USE OF EPINEPHRIN IN HEART BLOCK *}

$$
\begin{aligned}
& \text { H. M. KORNS, M.D. } \\
& \text { C. D. CHRISTIE, M.D. } \\
& \text { Cleveland }
\end{aligned}
$$

Phear and Parkinson ${ }^{1}$ recently reported a case of somplete heart block in which the sudden ventricular standstill responsible for syncopal attacks was entirely prevented by the subcutaneous injection of epinephrin. The heart block and the auricular and ventricular rates remained unchanged. Their review of the continental literature discloses only two cases, one of partial $(2: 1)$ block, the other of complete block, in which heart block was reduced or abated by epinephrin. In no case was partial heart block increased in degree, but in nearly all instances the auricular and ventricular rates were accelerated. Experimentally, however, it was shown by Kahn that complete auriculoventricular block may be produced in dogs by the intravenous injection of epinephrin. The paradoxical results reported by Routier, who describes a deblocking effect of epinephrin in dogs in which complete block had been produced by crushing the auriculoventricular bundle, failed of confirmation in the hands of Hardoy and Houssay and Clerc and Pezzi. Experimentally, also, the auricular and ventricular rates are usually accelerated by the drug.

The experience of Parkinson led one of us (C. D. C.) to suggest a trial of epinephrin in the case of heart block here described, although at the time the patient was free from syncopal attacks.

\section{REPORT OF CASE}

A woman, aged 56, had suffered for several years from a choking sensation while eating, often accompanied by nausea and vomiting, sometimes followed by faintness and complete loss of consciousness. The slightest exertion was sufficient to bring on severe air hunger. She was aware of the fact that her pulse was always very slow. Nothing to account for heart block could be discovered in the history.

On examination there was no enlargement of any of the chambers of the heart, nor any valvular defect. The ventricular rate was unusually slow. The beat of the auricles was not audible over the precordia, and the auricular component of the jugular pulse was lacking. The peripheral pulse was regular, rhythmic, monocrotic and "celer" in character. The systolic blood pressure varied between 140 and 175 , and the diastolic between 65 and 80 . There were no other physical findings of importance.

The blood Wassermann reaction was negative on three separate occasions. The patient received a total of $0.532 \mathrm{gm}$. of red mercuric iodid by intramuscular injection, during a period of thirty-four days, without effect on the heart block. Atropin, given to full physiologic effect, produced no change in the block or the ventricular rate.

Electrocardiograms substantiated the clinical diagnosis of heart block. From time to time the block varied in degree from partial (always 2:1) to complete. When complete heart block was present, the ventricular rate varied between 25 and 35 a minute. The highest rate recorded was 60 a minute, occurring during a period of incomplete block.

* From the Medical Clinic of Lakeside Hospital and Western Reserve University.
1. Phear, A. G., and Prrkinson, J.: Lancet 1:933 (May 13) 1922.
The effect of epinephrin is summarized in the accompanying table. In addition, epinephrin was twice tried without electrocardiographic control. On these occasions the highest ventricular rate recorded, including premature beàts, was 56 a minute. The original rate had returned within four hours after the injection. Death from inhibition of the ventricle occurred three days after the last experiment with epinephrin, before opportunity had been afforded to try the effect of this drug on the atropinized heart. Permission for necropsy was not given.

\section{COMMENT}

Interest in this case centers about three points: (1) increase in degree of auriculoventricular block; (2) increase in auricular and ventricular rates, and (3) production of auricular arrhythmia.

It is clear that the vagus was in no way responsible for the patient's heart block, as full atropinization was without effect. The immediate change from partial to complete block under epinephrin, however, was a central vagus effect. Although circumstances did not permit us to prove this directly by testing the epine-

\begin{tabular}{|c|c|c|c|c|c|c|c|}
\hline \multirow{4}{*}{$\begin{array}{l}\text { No. } \\
\text { con- } \\
\text { trol }\end{array}$} & \multirow{3}{*}{$\begin{array}{l}\text { Time } \\
3: 20\end{array}$} & \multirow{4}{*}{$\begin{array}{c}\text { Degree } \\
\text { of } \\
\text { Block } \\
\text { Partial } \\
2: 1 \\
\text { Ten minim }\end{array}$} & \multicolumn{2}{|c|}{ Rate * } & \multirow{3}{*}{$\begin{array}{c}\text { Premature } \\
\text { Ventricular } \\
\text { Beats } \\
\text { None }\end{array}$} & \multicolumn{2}{|c|}{$\begin{array}{c}\begin{array}{c}\text { Blood } \\
\text { Pressure }\end{array} \\
\end{array}$} \\
\hline & & & Auricle & Ventricle & & $\begin{array}{l}\text { Sys. } \\
\text { tolic }\end{array}$ & $\begin{array}{l}\text { Dias- } \\
\text { tolic }\end{array}$ \\
\hline & & & 70 & 35 & & & 78 \\
\hline & $3: 30$ & & of $1: 1,000$ solv & ation of epi & inephrin injec & ted & \\
\hline 1 & $3: 33$ & $\begin{array}{l}\text { Com- } \\
\text { plete }\end{array}$ & 100 & 40 & None & 154 & 80 \\
\hline 2 & $\ldots$ & $\begin{array}{l}\text { Com- } \\
\text { plete }\end{array}$ & $\begin{array}{l}\text { Extremely } \\
\text { arrhythmic }\end{array}$ & 41.6 & $\begin{array}{l}\text { Occa- } \\
\text { sional }\end{array}$ & 158 & 82 \\
\hline 8 & $\ldots$ & $\begin{array}{l}\text { Com- } \\
\text { plete }\end{array}$ & $\begin{array}{l}\text { Extremely } \\
\text { arrhythmic }\end{array}$ & 40 & $\begin{array}{c}\text { Promi- } \\
\text { nent }\end{array}$ & 154 & 78 \\
\hline 4 & $\cdots$ & $\begin{array}{c}\text { Partial } \\
2: 1\end{array}$ & $\begin{array}{l}\text { Extremely } \\
\text { arrhythmic }\end{array}$ & 45 & $\begin{array}{c}\text { Promi- } \\
\text { nent }\end{array}$ & 152 & 74 \\
\hline $5 \mathrm{~A}$ & $\ldots$ & $\begin{array}{l}\text { Com- } \\
\text { plete }\end{array}$ & $\begin{array}{l}\text { Extremely } \\
\text { arrhythmic }\end{array}$ & 40 & $\begin{array}{l}\text { Promi- } \\
\text { nent }\end{array}$ & $\cdots$ & $\because$ \\
\hline $5 \mathrm{~B}$ & $\cdots$ & $\begin{array}{c}\text { Partial } \\
2: 1\end{array}$ & 94 & 47 & $\underset{\text { Promi- }}{\text { nent }}$ & $\cdots$ & 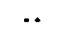 \\
\hline 6 & $\cdots$ & $\begin{array}{c}\text { Partial } \\
2: 1\end{array}$ & 102 & 51 & $\begin{array}{l}\text { Promi- } \\
\text { nent }\end{array}$ & 142 & 68 \\
\hline 7 & $\ldots$ & $\begin{array}{c}\text { Partial } \\
2: 1\end{array}$ & 96 & 48 & $\underset{\text { Promi- }}{\text { nent }}$ & $\cdots$ & ・. \\
\hline 8 & $3: 45$ & $\begin{array}{c}\text { Partial } \\
2: 1\end{array}$ & $\begin{array}{l}\text { Extremely } \\
\text { arrhythmie }\end{array}$ & $\cdots$ & $\underset{\text { Promt- }}{\text { Pent }}$ & $\cdots$ & . \\
\hline
\end{tabular}
phrin effect on the atropinized heart, it is fully substantiated by the experimental observation ${ }^{2}$ that

FFFECT OF EPINEPHRIN

* Exclusive of premature beats.

auriculoventricular block is not produced by epinephrin if the vagi have been cut. The vagi, therefore, retained a certain amount of tone, irrespective of the preexisting partial heart block. Production of auriculoventricular block in a patient by the action of epinephrin has not been previously described, so far as we are aware; but it cannot be considered an anomalous occurrence in view of the fact that epinephrin is known to stimulate the vagus strongly. In fact, from the available experimental data, it is much easier to explain the production of heart block by epinephrin than it is to understand how the reverse effect may be obtained. It becomes necessary, therefore, to accord this fact important consideration in dealing with cases of heart block.

It has been shown by Meek and Eyster, ${ }^{3}$ and Hoskins and Lovelette, ${ }^{4}$ that the mechanism of epinephrin action on the heart rate is probably twofold: it accelerates by direct stimulation and inhibits reflexly through the vagus. If the vagi possess good tone the resultant of these opposing actions is a slowing, but

2. Lewis: Mechanism and Graphic Registration of the Heart Beat, Shaw and Sons, 1920 , p. 164.

3. Meek and Eyster: Am. J. Physiol. 38 : 62, 1915

4. Hoskins and Lovelette: The Adrenals and the Pulse Rate, J. A. M. A. 63: 316 (July 25) 1914 . 
if the vagus tone is low the heart is usually accelerated. Vagal slowing is conditioned chiefly on rise of intraaortic pressure. In our patient, although the blood pressure was somewhat raised, a striking increase in auricular and ventricular rates took place. This result points clearly to a considerable lowering of vagal tone. . The extreme auricular arrhythmia manifested under epinephrin is due primarily to disturbance in vagal tone referable to the central epinephrin effect and to variations which take place with each arterial pulse. Additional factors may be the raised ventricular rate and disturbance in ventricular rhythm caused by numerous premature beats. Systole of the ventricle is known to influence impulse formation in the auricle, and this influence is most apparent in auriculoventricular block. ${ }^{5}$

\section{SUMMARY}

1. There are on record a few instances in which epinephrin reduced or abolished auriculoventricular block. The report of our case illustrates the fact that epinephrin may also increase a preexisting partial auriculoventricular block. The increase is probably a central vagus effect. The mechanism by which epinephrin reduces auriculoventricular block is not clear.

2. Increase in auricular and ventricular rates, excitation of premature ventricular beats and production of extreme auricular arrhythmia may be brought about by the action of epinephrin on a heart which is the seat of auriculoventricular block.

\section{Clinical Notes, Suggestions, and New Instruments}

INTRA-ABDOMINAL HEMORRHAGE FROM STOMACH DUE TO OSTEOPATHIC TREATMENT: REPORT OF CASE B. J. O'Neill, B.S., M.D., ANd W. W. Crawford, M.D., San Diego, Calif.

This case is reported because it illustrates one of the possible dangers of indiscriminate mechanotherapy.

History.-A woman, aged 22, single, eleven hours before admission, had been seized with severe abdominal pain and slight vomiting shortly after eating radishes, which had always disagreed with her. A person calling himself an osteologist, and claiming to be an improvement over the osteopath, was called in and subjected her to vigorous abdominal massage, followed by manipulation of the neck. To accomplish this, he threw her face downward over his knee, striking her abdomen against his knee. This caused an immediate increase in the abdominal pain, of such a degree that the osteologist was ordered out of the house. Pain continued, became colicky in character, and vomiting increased. The patient was taken to the hospital for treatment. The past history was negative, except for some indigestion and some slight pain on menstruation.

Examination.-The patient was well developed and well nourished. She was lying on her back with the knees drawn up. She was extremely pale, presenting a picture of collapse, with short and gasping respiration. She complained of pain over the entire abdomen, which increased on deep respiration. The abdomen was rigid and tender, the condition being rather more marked below the umbilicus. There was movable fluid in the flanks. The heart and lungs were normal; there was no vaginal flow; the hymen was intact. The white blood corpuscles numbered 12,500; polymorphonuclears; 92 per cent.; red blood corpuscles, 3,136,000; hemoglobin, 80 per cent. (Tallquist).

Treatment and Result.-Diagnosis of probable ruptured appendix was made and immediate laparotomy undertaken.

\footnotetext{
5. Lewis (Footnote 2) p. 177.
}

When the abdomen was opened, slightly to the right of the median line, there was a gush of bright red blood and about 3 pints ( 1.5 liters) of fluid and clotted blood was removed with the fingers, swabs and pump, the clots being of varying consistency, none more than a few hours old. Careful exploration of the abdomen and pelvis revealed no abnormalities except a bleeding point on the greater curvature of the stomach; some adhesions about the gallbladder and appendix, which was small, fibrous and kinked in the middle, and a small cyst of the right ovary. The fallopian tubes were normal. The stomach extended below the umbilicus, and there was bleeding from a ruptured branch of the gastroepiploic vein on the anterior surface of the stomach, about half an inch from the border of the stomach, at the point at which the stomach crossed the spinal column. This was tied with fine catgut. Toilet of the peritoneum was completed, and the abdomen was closed with a small rubber drainage tube in the pelvis. Recovery was uneventful.

At present, one year after operation, the patient is in good condition, except for some indigestion, probably due to chronic appendicitis.

A damage suit against the osteologist was decided in his favor by a jury, who apparently adopted the view that the bleeding was caused by vomiting.

824 First National Bank Building.

ARTIFICIAL PNEUMOTHORAX COMPLICATED BY HYDROPN'EUMOTHORAX AND PLEURISY WITH EFFUSION ON THE UNTREATED SIDE: REPORT OF TWO CASES

LeRoy S. Peters, M.D., Albuquerque, N. M.

There are few reports in the literature of the coexistence of bilateral pleurisy with effusion. In fact, it is one of the rarest complications in pulmonary tuberculosis. Stivelman reported a close search of the literature, and could find but two cases, one reported by $\mathrm{Als}^{2}$ and one by Fishberg, ${ }^{3}$ the latter being the first one in the English language. Zemmin reported one in 1921, which, with Stivelman's case, brings the number up to four. Two have occurred in my practice during the administration of artificial pneumothorax:

CASE 1.-One of these came under my observation while I was associated with the late Dr. A. G. Shortle at the. Albuquerque Sanatorium, six years ago. The records of this case were accidentally destroyed by fire, but I remember the essential details. The patient was started on pneumothorax treatment at Colorado Springs, fluid developing on the treated side before he came to Albuquerque. While he was on the train, marked dyspnea developed, and when seen by us his discomfort was extreme. Examination revealed a well compressed left lung, with dulness over the right lung from the fourth rib to the base. Aspiration of 2 quarts (liters) of serous fluid gave him immediate relief, and there was no further accumulation. This patient died later of complications not referable to the pneumothorax.

CASE 2.-The other patient, admitted four years ago, was under my care at St. Joseph Sanatorium, Albuquerque. At that time she gave a history of active tuberculosis, extending back two years. A few months prior to consulting me she had gone through a normal pregnancy, but the disease had become more active after delivery. The left lung was completely involved, with cavity formation in the upper lobe, and there was a moderate infiltration in the right upper lobe. The daily average maximum temperature was $100 \mathrm{~F}$. During the entire period of her history she had had repeated hemorrhages, and a pneumothorax was advised. This was easily produced and continued for nearly a year, when fluid formed on the compressed side. This later became purulent, lut at no time could we demonstrate a mixed infection, and as far as symptoms were concerned there was no evidence of the change from a serous to a purulent exudate. This

1. Stivelman, B. P.: Am. J. M. Sc. 162:270 (Aug.) 1921

2. Als, E. (Ztschr. f. Tuberk. 31: 333 [Feb.] 1920), cited by Stivel. m.

3. Fishberg, M. (Am. Rev. Tuberc. 4: 649 [Nov.] 1920), cited by Stivelman.

4. Zemmin: Beitr. z. Klin. d. Tuberk. 47:169 (April 11) 1921. 